\section{Mammalian diversity in the National Park of Upper Niger, Republic of Guinea - an update}

Ziegler et al. (2002) presented the results of a mammal survey conducted during 1995-1997 in the newly established National Park of Upper Niger in the Republic of Guinea, West Africa. We have carried out further surveys of the mammals of the Park since 2000, and are able to provide some significant updates to the list of recorded mammals (Table 1 in Ziegler et al., 2002).

Although listed as formerly present but now disappeared, there is evidence that both lion Panthera leo and manatee Trichechus senegalensis now occur in the Park. Lions returned in 1997-1998, probably from an area to the north of the Park along the Tinkisso river, where this species has always been present. This return is possibly a result of the Park's creation in January 1997 and the consequent reduction in hunting pressure in Mafou Forest (the Park's core area of $554 \mathrm{~km}^{2}$ ). A population of resident lions is now established in the northern part of the Park, and we estimate that there are 5-8 individuals in Mafou Forest. There is now evidence that manatees occur in the river Niger where it passes through the Park. Three individuals were observed in 2000 in the section of the Niger that borders Mafou Forest (Camara et al., 2000). In November 2001 we carried out a 4-day survey along the same section and, although we did not observe manatees, we found evidence of typical manatee grazing on the aquatic vegetation at a number of sites (manatee grazing is characteristically different from that of Hippopotamus amphibius).

The occurrence of the bush duiker Sylvicapra grimmia in the park is questionable. Ziegler et al. (2002) listed this species based on accounts from hunters in one village and a skin that could have been from the species (S. Ziegler, pers. comm.). However, the species was neither recorded by Toure et al. (1997) during a mammal census carried out in 1997 in Mafou Forest, nor during a $838 \mathrm{~km}$ transect census that we carried out in Mafou Forest in 2002 (Brugière et al., 2002).

The roan antelope Hippotragus equinus is only a vagrant species in the Park, with lone individuals or small herds occasionally observed in the north. These observations occur mainly during the dry season, when herds of roan antelope leave the areas along the Tinkisso river to reach the river Niger, probably in search of grazing. These observations have become increasingly scarce over the past 10 years, and it is probable that the migration pattern of this species is now disturbed by the numerous human settlements established along the northern boundary of the Park.

We believe that two species can be added to the list of artiodactyls: the oribi Ourebia ourebi and the water chevrotain Hyemoschus aquaticus. An adult male oribi was observed during our 2002 mammal census (Brugière et al., 2002), and two specimens were observed in 2001. The Mafou Forest is probably the southern limit of the distribution of this species in Guinea. We took pictures in February 2002 of a fresh skin of the water chevrotain in Sidokoro village, within the Park. According to hunters this species is rare and restricted to the gallery forests that border the Niger river.

We thank R. Hutterer and S. Ziegler for their comments.

David Brugière E Bakary Magassouba

Parc National du Haut Niger

Projet AGIR, BP 730 Conakry, Guinea

E-mail: dmc_brugiere@yahoo.fr

\section{References}

Brugière, D., Dia, M., Magassouba, M., Diakite, S., Gbansara, M., Saliou, B. \& Mamy, M. (2002) Dénombrement des moyens et grands mammiferes dans la ZIP Mafou, Parc National du Haut Niger. Rapport au projet AGIR, Conakry, Guinea.

Camara, A., Oulare, K. \& Oulare, L. (2000) Inventaire et distribution du lamantin d'Afrique (Trichechus senegalensis) dans la zone intégralement protégée du Parc National du Haut-Niger. Mémoire de fin d'études, ISAV, Faranah, Guinea.

Ziegler, S., Nikolaus, G. \& Hutterer, R. (2002) High mammalian diversity in the newly established National Park of Upper Niger, Republic of Guinea. Oryx, 36, 73-80.

Toure, S., Soumah, S. \& Alberti, A. (1997) Inventaire, distribution et abondance des mammiferes dans le Parc National du Haut-Niger (Guinée). Rapport au projet PRABV, Conakry, Guinea. 